the securing of the safety of the city at night. The next step in advance was the invention in 1774 by the Abbé Matherot de Perigny of an oil lamp with a silvered reflector. The way in which this reflector distributed the light led some to think that nothing better could be invented in the future. During the Revolution, some of these lamps were suspended by pylons and some by span wires fastened across the street at a height of about $16 \mathrm{ft}$. The lamps obstructed the traffic when they had to be trimmed and their containers replenished. By the use of Argand burners in 1821, the lighting was improved. The first gas lamps were placed in the Place du Carrousel in 1829. The number of flat-flame gas lamps, each burner giving a modest light of about 10 candle power, increased from 14,000 to 21,000 between 1839 and 1870. Jablochkoff electric candles were used in 1878 to light the Avenue de I'Opéra, and people still living can remember the spluttering carbons and the fluctuating light they gave. At the Paris Exhibition of 1900, it was still doubtful whether lighting by incandescent gas mantles or open arc lamps was the better. At that date there were 50,900 street lamps in Paris. It would be unsafe to prophesy how it will be illuminated twenty years hence.

\section{Decreasing Barn-Owls}

ONE of the outcomes of the census of barn-owls (Tyto alba alba) in England and Wales (Blaker, Bird Notes and News, 15, 7) is substantiating the fears that this useful bird is on the decline in Britain. Northumberland, Cumberland and Durham were the only counties to report an increase. The areas of maximum population (41-50 pairs per $100 \mathrm{sq}$. miles) appear to be Anglesey, Devon, Durham and parts of Essex, Suffolk and Hertford, and that of minimum population $(0-5$ pairs per 100 sq. miles), a mountainous area of north-east Lancashire and north-west Riding. About 4,000 naturalists took part in this census, organised by the Royal Society for the Protection of Birds, and found about 12,000 breeding pairs for England and Wales in the summer of 1932, non-breeding birds averaging one per $50 \mathrm{sq}$. miles. Some 45,000 eggs were laid in 1932 , of which 35,000 hatched and 33,000 owlets left the nest, when the country would contain 55,000 barn-owls, which, by the following spring, would be reduced to 24,000 . The species seems to have declined 50 per cent in the past ten years, and is declining at about 1,000 a year, or four per cent. Of 214 nests examined, 807 eggs were laid, 174 of which failed to hatch, and of the 633 owlets, 594 left the nest. There is a marked spreading over the countryside at the end of the nesting season, which accounts for the presence of the birds in areas otherwise rarely inhabited. Mr. Blaker considers that the decline of the species could be averted if four per cent of the death-rate was stopped. The Royal Society for the Protection of Birds is to issue the complete census results in pamphlet form. The barn-owl, which was once the commonest owl in Britain, is nowhere now so numerous as the tawnyowl, nor in many places as the alien little owl. The food of the barn-owl consists of 69 per cent voles and mice (Collinge).

\section{Ceylon Fisheries}

THE administrative report of the Marine Biologist of Ceylon (Dr. Joseph Pearson) for 1932 shows that the work of the Department has been greatly restricted for lack of funds. No oysters were seen on the pearl banks during the January-March survey. All the potential paar areas are surveyed at least once in three years. The isolated patches of young oysters found in the Gulf of Manaar show little promise for fisheries in the near future. The windowpane oyster fishery in Lake Tamblegam should do well if no fishery is held this year and provided that no abnormally heavy rains occur during the intervening north-west monsoon. There are also oysters in the lake which should be fishable in 1936 and 1937, and as there are many brood oysters the chances of new spatfalls are hopeful. The chank fishery was carried on in the Palk Strait but the average of chanks exported was much less in 1931-32 than in 1930 . With regard to the development of the fishery industry, there is still the question of modern boats and gear. It is now proposed to enlist the services of a master fisherman skilled in small boat fishing with modern apparatus, for the purpose of making initial investigations, and to train a local crew in the proper use of the boat and gear, instead of appointing a new marine superintendent who would not be so skilled in this type of work. It is also proposed to purchase a small boat, suitable for the use of the fishermen, to serve as a model for adoption. The purchase of this boat would, however, not be possible until the investigations have been carried far enough to indicate the type most suitable.

\section{Vibrations due to Traffic in Oxford}

The Milne-Shaw seismograph has lately been employed for the purpose of estimating the amount of vibration caused by the passage of heavy traffic along the main streets of Oxford, and the consequent damage likely to result to the buildings of the city. A comparison of the readings of seismographs in position at the University Observatory and in the High Street respectively, taken at the same time and for the same duration, showed in the former case an almost imperceptible amount of vibration, but in the latter a record of disturbance which clearly indicated a serious menace to the stability of buildings ulong the route, especially of the older structures belonging to the University and Colleges.

\section{Tables of Alcoholic Strength}

There has been recently issued by H.M. Stationery Office new tables correlating percentages of proof spirit and percentages of alcohol by weight with specific gravity at $80^{\circ} \mathrm{F}$, compiled by Mr. Francis G. H. Tate, of the Government Laboratory $(2 s .6 d$. net), whose well-known book on the British system of alcoholometry entitled "Alcoholometry : an Account. of the British Method of Alcoholic Strength Determination" was noticed in our columns in March 1931. 